\title{
8.2 Перспективи розвитку правоохоронної діяльності у Збройних силах України
}

Конституція України проголошує Україну правовою державою. Однією 3 найважливіших основ цієї держави є верховенство права, яке закріплене у статті 8 Конституції. Реалізація цього конституційного положення зумовлює необхідність охорони права, яка здійснюється за допомогою правоохоронних функцій держави. Ефективність реалізації цих функцій залежить від злагодженої діяльності суб'єктів, які призначені для їх здійснення, серед яких провідна роль належить правоохоронним органам держави.

Окремі правоохоронні органи здійснюють спеціальну правоохоронну діяльність, що відповідає їх назві, особливому статусу в механізмі правового регулювання. Предмет правоохоронної діяльності є специфічним за конкретно нормативно-визначеними функціями. Одним із таких правоохоронних органів $\epsilon$ Військова Служба правопорядку у Збройних Силах України.

3 метою подальшого зміцнення законності, правопорядку та військової дисципліни у Збройних Силах України, забезпечення конституційних прав військовослужбовців, Верховна Рада України у 2002 році прийняла Закон України "Про Військову службу правопорядку у Збройних Силах України”, відповідно до якого було створено Військову службу правопорядку у Збройних Силах України - спеціальне правоохоронне формування в складі Збройних Сил України, призначене для запобігання злочинам, іншим правопорушенням, їх розкриття і припинення, а також виконання інших визначених Законом завдань правоохоронної діяльності. Такі завдання відносяться до основних завдань Служби правопорядку та відповідають меті ії створення[140].

Необхідним атрибутом держави виступають Збройні Сили, які є гарантом національної безпеки України й стабільності в суспільстві. Конституція України встановлює місце і роль Збройних Сил у системі української державності, що визначаються головним призначенням, яке покладається на Збройні Сили України - “оборона України, захист її суверенітету, територіальної цілісності і 
недоторканності”. Наша держава обрала шлях вступу до НАТО, а отже реформи Збройних Сил мають відбуватися по відповідним стандартам. Президент доручив керівництву Міноборони створити військову поліцію (ВП). Згідно із повідомленнями прес-служби Офісу президента: “Міністр оборони Андрій Загороднюк до 31 грудня має впровадити нову об’єднану систему керівництва та управління силами оборони, яка відповідатиме стандартам НАТО. Крім того, у структурі Міноборони має бути створений сучасний ефективний правоохоронний орган - Військова поліція"[141].

Утворення в системі Міністерства оборони України Військової поліції, як правоохоронного органу, віднесено до невідкладних заходів 3 проведення реформ та зміцнення держави [142]. Проте дискусії щодо структури, функцій та завдань зазначеного правоохоронного органу тривають вже понад 10 років.

Основними тенденціями реформування Військової служби правопорядку у Збройних Силах України є надання їй повноважень щодо здійснення досудового розслідування кримінальних правопорушень та ведення оперативно-розшукової діяльності, а також створення на її основі Військової поліції.

Поділяємо думку Д. Зархіна щодо основних завдань та функцій, які доцільно було $б$ законодавчо покласти на Військову поліцію, зокрема: запобігання, виявлення і припинення кримінальних правопорушень у Збройних Силах України та у системі Міністерства оборони України; досудове розслідування кримінальних правопорушень, учинених військовослужбовцями, віднесених законом до їх підслідності; розшук та затримання військовослужбовців, які самовільно залишили військові частини чи місця служби, а також тих, які переховуються від органів досудового розслідування або суду, чи засуджених, які ухиляються відвідбування кримінальних покарань; розшук вогнепальної зброї, боєприпасів до неї або вибухових речовин, викрадених або втрачених у військовослужбовців; захист військового майна від злочинних посягань; участь у протидії диверсійним проявам та терористичним актам на військових об'єктах [143]. 
Однак, необхідність приведення військової сфери України до стандартів НАТО потребує вивчення іноземного досвіду, який може стати в нагоді при реформуванні системи військової юстиції України.

Результати аналізу спеціальної та фахової літератури щодо системи військової юстиції іноземних держав дозволили дійти висновку, що Військова поліція є складовим елементом системи військової юстиції та здійснює досудове розслідування військових злочинів а також забезпечує підтримання правопорядку у військовій сфері. Переважна більшість провідних країн-членів НАТО мають у складі системи військової юстиції Військову поліцію, яка наділена певними функціями.

Важливим у рамках дослідження є праця С. Мельника [144], у якій науковець розкриває теоретичні та практичні аспекти організації системи військової юстиції в країнах членах НАТО. Розглянемо окремі з них.

Корпус військової поліції США як окремий рід військ був створений у 1941 році. На нього покладено такі завдання: розслідування злочинів у Збройних силах; контроль за дотриманням законності; профілактика дисциплінарних правопорушень; контроль i регулювання руху військового транспорту; забезпечення безпеки військовослужбовців; охорона військових об'єктів тощо. Загалом органи військової поліції Збройних сил США налічують понад 30 тис. осіб. Очолює військову поліцію США начальник військової поліції - заступник генерального інспектора сухопутних військ.

Військова поліція Канади, яка забезпечує підтримання правопорядку у Збройних силах Канади та розслідування вчинених військовослужбовцями правопорушень. Кількість військових поліцейських становить $2 \%$ від загальної кількості військово-службовців. Органи військової поліції діють автономно від військового командування і підпорядковуються начальнику військової поліції Збройних сил Канади.

Функції військової поліції в Італії виконують карабінери - військові, організовані за територіальною ознакою як для національних, так i для міжнародних місій. 3 питань оборони вони підпорядковуються Міністерству 
оборони Італії, з питань громадського порядку - Міністерству внутрішніх справ Італії.

У Франції функції військової поліції виконує Національна жандармерія, яка має подвійне підпорядкування: Міністру оборони Франції (як складова Збройних Сил) та Міністру внутрішніх справ (як складова системи поліції). Її очолює Генеральний директор. Чисельність Національна жандармерії становить близько 110 тис. співробітників. До неї входять також республіканська гвардія, мобільна жандармерія, підрозділи, що дислокуються за межами Франції.

Військова поліція ФРН налічує близько 4,5 тис. осіб. В мирний час військові поліцейські охороняють військові об’єкти, органи управління, забезпечують безпеку транспортних перевезень, підтримують дисципліну у військових формуваннях тощо. Військова поліція не має центрального командування, а керівництво їі підрозділами здійснює командир дивізії через штаб.

Окремої уваги заслуговує досвід побудови ефективної системи військової юстиції у Ізраїлі. Основною функцією військової поліції є розслідування вчинених військовослужбовцями злочинів. Крім того, до іiі компетенції також належить контроль над затриманими та взятими під варту солдатами Армії оборони Ізраїлю, патрулювання, попередження дисциплінарних порушень, а у військовий час - також контроль над військовополоненими і забезпечення порядку під час пересування бойових та допоміжних частин. Військова поліція підпорядковується Управлінню особового складу Генштабу. Її очолює керівник у званні генерал-майора, який командує військовою поліцією через штаб.

Наприклад, Канада допомагає в організації та проведенні курсу застосування сили, надає матеріально-технічну допомогу, консультує з переходу на Ј-структуру. Чехія - курси ведення слідства, в планах - курс підготовки спецпризначенців. Польські колеги організовують курси лідерства та допомагають із втіленням доктрини Воєнної поліції. Правоохоронці Великої Британії проводять курси утримання засуджених, бою в місті та надання першої медичної допомоги. Литовські партнери влаштовують курси організації i проведення поліцейських операцій, курси виживання та курси охорони VIP- 
персон. Данія запрошує на курси підготовки військових поліцейських. Колеги із Сполучених Штатів Америки сприяють в наданні матеріально-технічної допомоги[145].

У Національному варіанті військова поліція має бути військовим правоохоронним формуванням, завданням якого буде забезпечення правопорядку серед військовослужбовців, військовозобов'язаних та резервістів під час проходження ними військових зборів; запобігання, виявлення кримінальних та інших правопорушень, вчинених військовослужбовцями, а також працівниками Міністерства оборони і Збройних сил України, їх розкриття й припинення.

Крім того, в залежності від завдань покладених на територіальні органи (військові частини) Військової поліції до їх складу включаються структурні підрозділи: слідчі, оперативно-розшукові, запобігання, виявлення злочинів та інших правопорушень, охорони, патрульно-постової служби та розшуку, військової інспекції безпеки дорожнього руху, спеціального призначення, службових розслідувань, режимної служби, підрозділи Військової поліції в окремих гарнізонах, підрозділи, які забезпечують виконання завдань за призначенням та повсякденну діяльність Військової поліції.

Також на нашу думку потрібно передбачити питання захисту прав підозрюваних у військових злочинах, адже кожен має право на захист. Необхідно відповісти на питання: Чи можуть це робити адвокати, які спеціалізуються на кримінальних справах? Наскільки компетентні суди загальної юрисдикції? Колись існував військовий трибунал, однак до його неупередженості було багато питань. Військових судів немає. Важливим моментом є військова таємниця: Якщо злочин пов'язаний з військовою таємницею, то звичайний суд не може його розглядати. Те ж саме можна сказати про адвокатів.

Отже, узагальнюючи міжнародний досвід організації функціонування військової поліції вважаємо, що реформування правоохоронної системи України повинно передбачати його глибокий аналіз та відповідність національному законодавству. Військова поліція удосконалить організацію забезпечення 
правопорядку й законності в Міноборони і Збройних Силах України, правоохоронних органах спеціального призначення та інших військових формуваннях. Також буде забезпечено можливості ефективно й оперативно здійснювати розслідування найбільш поширених військових злочинів, що позитивно вплине на рівень національної безпеки держави. 